\title{
PROPHYLAXIS OF SCHOOL BULLYING AT TRAINING FUTURE TEACHERS OF FOREIGN LANGUAGES
}

\author{
Ganna Polishchuk \\ Department of the English Language and its Teaching Methods \\ Volodymyr Vynnychenko Central Ukrainian State Pedagogical University \\ 1 Shevchenko str., Kropyvnytskyi, Ukraine, 25006 \\ lopotova@ukr.net
}

\begin{abstract}
The article reveals the essence of bullying as a social aggression or social situation that arises in a group; psychological features of bullies, their victims and observers; modern types of bullying (physical, verbal, social, cyberbullying); psychological peculiarities of interpersonal relations of students of higher education institutions with experience of school bullying. The authors have conducted an experimental research with future foreign language teachers using the method of interpersonal perception in a conflict situation (A. Tatishcheva in the modification of O. Misenko) to clarify students' understanding of such concepts as "bullying" and "conflict" and they have analyzed the results. It was found, that only one fifth of the respondents (20.64 \%) clearly understood the essential features of the "conflict" concept, and have understood the mechanisms of perception of conflict situations (high level); half of the respondents (50.16\%) were partially able to characterize the phenomenon of the study (middle level), and a third (29.20\%) - completely did not understand the meaningful field of the concept of "conflict", and have experienced great difficulty in correlating this concept with others (low level). The obtained empirical data shows that the students did not get adequate knowledge in the course of their life on the identified problems, had no idea about conflict situations solving strategies. This has led to the need for focused work to clarify the nature of the «conflict» and other concepts related to it («bullying», «mobbing», «violence», etc.). The article offers modern forms and methods of teaching students' prevention and overcoming school bullying, like: case study, webinars, individual conversations with students during pedagogical practice, announcements in the form of mini-lectures at parental meetings and more.

Keywords: aggression, bullying, bullies, victims, observers, physical and psychological terror, conflict, future foreign
\end{abstract} language teachers, webinar, mini-lecture, cases.

DOI: 10.21303/2504-5571.2020.001438

\section{Introduction}

One of most urgent modern problems of the world is bullying. Statistical data testify that $20.2 \%$ of youth from 12 to 18 years suffered from humiliations at higher educational institutions or at school $[1$, p. 6]. The problem of bullying of youth is real and needs decisive actions for fighting against this phenomenon.

Special attention in overcoming this phenomenon, negative for society, is paid to a modern young teacher, who master in student years effective ways, forms and methods of solving conflict situations in the school environment. The problem of formation of conflictological competence of future teachers, especially ones of foreign languages as an integral personal construction, based on the system of scientific knowledge about conflict, skills, practical experience of solving conflicts, purposefully developed in the process of conflictological training at higher educational institutions, also becomes urgent.

Teachers of foreign languages are able not only to train students for communication in another language successfully, but develop the culture of interrelations of schoolchildren, tolerance and mutual respect to people of other races and nations.

One of priority tasks in elaboration of this problem is one of competence formation of pedagogical workers in revelation and differentiation of bullying signs, its prophylaxis and overcoming, highlighted in works of a series of scientists. Thus, T. Ielchaninova, E. Pidchasov, E. Ziza, L. Karlashova, I. Filippska developed a program of bullying prophylaxis and prevention that became a ground of a seminar-training for pedagogical workers, based on the theoretical analysis and key characteristics of it [2]. O. Kairis and A. Samoilenko presented results of a comparative study of peculiarities of' interpersonal relations of students at higher educational institutions with or without an experience of bullying at school [3]. C. Bradshaw, T. Waasdorp, E. Pas, K. Larson, 
S. Johnson offered a new approach to bullying overcoming at class using an adapted version of the training model Classroom Check-Up that together with the simulator of combined reality TeachLivE favored the improvement of teachers' skills in prevention, revelation and reaction on youth humiliation [4]. H. Murphy, J. Tubritt, J. Norman conducted a research and established that teachers' compassion is an important factor in creation and support of the positive school climate, resulting in prevention of humiliations [5]. So, teachers' attention to the problem of bullying in the process of professional training of future teachers proves its urgency and pressing necessity of solving.

Aim of research is to offer effective forms of increasing knowledge of future teachers of foreign languages for preventing and overcoming school bullying.

\section{Materials and methods}

The following methods were used in the study: theoretical analysis of literature, interrogation by the method of interpersonal perception in a conflict situation (by A. Tatischeva, modified by O. Misenko). The material for this study was selected among the great spectrum of native and foreign scientific papers and monographs on this problem of last years of edition.

Qualitative methods, based on analytical induction and generalization of research results, were used in the study. For widening knowledge of future teachers of foreign languages as to conflict and developing abilities and skills of bullying prophylaxis and prevention among youth, there were used such learning forms and methods as work with cases, problem questions, webinars. At the same time, students studied cases of bullying manifestations at school, conducted an independent work with schoolchildren at pedagogical practice (conversations, mini-lectures, training exercises).

\section{Result}

In the research process it has been discovered, that bullying (from bully-abuser, tease, violator, churl) is interpreted as baiting, discrimination, oppression. This term means a long process of a conscious cruel attitude (physical and psychical) of a child or group to another child or other children.

According to the research results, bullying is a complicated problem, interpreted by the scientists (G. Aleksienko, O. Barlit, G. Koval, I. Kon, O. Kormylo, L. Lushpay, C. Arora, V. Besag, D. Olweus and others) as a type of social aggression or social situation, appearing in a group; certain actions, youth's behavior, causing offence or stress feeling; intimidation, physical or psychical terror and so on.

We agree with research results by N. Honcharuk and L. Onufrieva, who prove the existence of three main characteristics of bullying as a system phenomenon:

1) non-formation of a development social situation of a group, manifested in disturbance of the group dynamics and stable status-role opposition;

2) presence of a directed aggressive attitude that certainly characterizes the atmosphere of relations in a group;

3) disturbance of group communication, resulting in interpersonal conflicts [6, p. 28-29].

O. Kormylo accents attention on the fact that "not each realized violence is bullying. The essence of bullying is found not just in abuser's aggression or malice, but in contempt, disrespect to a humble one, who is as if not worthy of respect. It allows abusers to harm without a feeling of blame, compassion or empathy" [7, p. 178-179]. The scientist proves that depending on means of aggression and baiting of bullying victims, it can be: physical - blows, pushes, damage or pilferage of property; verbal (oral, written form, including cyberbullying) - brutal naming, mockery or expressions, abusing gender, race or sexual orientation; writing messages or signs that may be painful or abusing; propagation of rumors or abusing comments by e-main, mobile phones (for example, SMS) and sites of social networks; social - exclusion from a group or propagation of gossips or rumors. The most noticeable is physical violence, it is less than one third of bullying cases. It is most difficult to notice emotional (social and verbal) cruel treatment. Today cyberbullying becomes widespread [7, p. 182]. G. Koval and G. Aleksienko consider typical manifestations of school bullying as physical (causing physical injuries to a child or risk of such injuries) and psychologi- 
cal (constant humiliations, abuses, mockery or terrorization) violence. Manifestations of sexual violence that are subspecies of physical violence occur less often among bullying components [8, p. 9]. Thus, most spread types of bullying are physical and psychological (social and emotional).

The central place in the development of bullying theory is occupied by works of the Norwegian psychologist D. Olweus. This scientist determined the role structure of bullying:

1) Pupil, who is a victim of bullying;

2) Schoolchildren, who realize violence, initiate and play leading roles ("bullies" or persecutors, aggressors);

3) followers - pupils, who treat a cruel treatment of others positively and actively participate in it, but are not initiators and don't play a central role;

4) passive "bullies" - pupils, who actively support bulling;

5) potential "bullies" - schoolchildren, who enjoy mockery, but they don't manifest it;

6) "observers" (indifferent witnesses) - pupils, who don't participate in bullying, manifest an indifferent attitude to a situation;

7) "potential defenders" - schoolchildren, who treat violence negatively and think that they must help a victim, but do nothing;

8) "defenders" - pupils, who manifest the negative attitude to the phenomenon, they defend a victim or try to help him/her [9].

At the same the scientist determined such typical features of pupils, who are disposed to become bullies: they feel a strong need to dominate and to subordinate other pupils to them, pursuing own aims, they are impulsive, easily agitated; they are often impudent and aggressive in their attitude to adults (first of all parents and teachers); they don't manifest compassion to their victims; boys are usually physically stronger than others. According to the scientist, typical victims of bullying also have own features: they are fearful, impressionable, closed and shy; they are often anxious, diffident, unhappy and have a low self-esteem; they are inclined to depression and think about suicide, communicate with adults more often than with peers; boys are often physically weaker than coevals [9]. So, in the process of bullying impulsiveness, aggression, cruelty, self-confidence, excessive self-esteem are typical for offenders, and for their victims - fearfulness, impressionability, closeness, shyness, diffidence, low self-esteem.

A. Borshchevska indicates that bullying may be a manifestation of different types of aggression, but it is closer to a mediated than to a direct form. Children, inclined to direct bullying, often suffer from the syndrome of hyperactivity, low socioability, has problems in communication with coevals. Whereas bullies, using indirect tactics of intimidation and terrorizing or machiavellism (the ability of a person to manipulate other's behavior for own use, ability to fox, to deceive, cunningly impose own ideas to other) are characterized by callousness, low level of empathy and chilly planning [10, p. 49]. Thus, bullies, practicing different types of humiliation and terrorizing have also different qualities, namely: ones, using direct bullying are characterized with hyperactivity, problems in communication, indirect ones - callousness, low empathy level.

N. Honcharuk and L. Onufrieva determine in their study not only psychological features of bullies and victims, but also observers. The scientists outline such variants of bullying observers' behavior: ones of them silently observe acts of bullying and don't hurry to take anyone's side - they wait and don't try to conflict with a bully because of fear to find oneself at the victim's place, other actively take side of a bully and help him/her in the act of violence, supporting by remarks, mockery or physically. According to the scientists, such children are characterized by the increased level of conformism that conditions a behavior, depending on a dominant influence. The third category of observers is characterized by the humanistic directionality and striving for helping a victim in a violence situation [6, p. 33]. So, psychological peculiarities of most observers are conformism or humanistic directionality.

We agree with an idea of L. Butuzova that psychologically the role of observer is the same important for bullying as the ones of victim and abuser, because observers are ones, that bullies work for, expecting for their certain emotional reactions: fear, enthusiasm, excitement and so on. The importance of this role in the bullying structure is underlined also by more "modern" form of bullying - cyberbullying - when just observers record videos with humiliation acts on mobile 
phones and post in the network. L. Butuzova interrogated students and discovered that in fact each third of them had an experience of participation and emotions as to school baiting, and $69 \%$ of the respondents identified themselves as bullying observers, at that they talked mainly about passive observation, not active counteractions to this phenomenon [11, p. 5-6]. So, more than two thirds of the students identified themselves as passive observers, characterized by conformism.

Results of school bullying may be manifested also in student years. Thus, research results of O. Kairis, A. Samoilenko as to psychological peculiarities of interpersonal relations between students of higher educational institutions with an experience of school bullying testify that main problems of people with an experience of bullying, comparing with ones, who has no such experience, are high subjugation level that is obedience, inclination to self-humiliation, inclination to blame oneself, increased level of dependence on others, other opinion. A bit less expressed are the high level of suspiciousness, alienation relative to the hostile and malicious world, injuriousness, disposition to doubts in all, spitefulness and decreased level of egoism, such people less appreciate themselves, less strive for domination [3, p. 28]. So, obedience, disposition to self-humiliation, increased level of dependence on other's opinions may form in people, influenced by school bullying.

For discovering students' understanding of such notions as "bullying" and "conflict" there was conducted the study with future teachers of foreign languages ( 315 persons), based on the Volodymyr Vynnychenko Central Ukrainian State Pedagogical University and SHEI "Pereyaslav-Khmelnitsky state university, named after Grigory Skovoroda”. The method of interpersonal perception in a conflict situation (A. Tatischeva, modified by O. Misenko) [12, p. 23-27] was used in the study by performing two tasks, namely: interpretation of the notion "conflict"; determination of the semantic kernel of this notion and content-analysis as to its scale belonging.

The experiment result testified that at determining essential signs of the notion "conflict", future teachers of foreign languages paid special attention on such its manifestations: controversy, clash (16.19\%), disagreement, contradiction (9.84\%), abuse (13.33\%), violence (moral - $27.62 \%$, physical $-7.30 \%$ ), defamation (17.14 \%) and other (opposition, snub, misunderstanding - $8.57 \%$ ). The semantic kernel of the term "conflict" consisted of the following assessment criteria: scuffle, quarrel, controversy, abuse, misunderstanding, defamation.

The conducted study demonstrated that only the unessential part of respondents $(16.51 \%)$ understood essential signs of conflict, more than a half (53.01\%) - noted unessential manifestations of conflict together with essential ones. Future teachers of foreign languages, who didn't understand essential signs of conflict were $30.48 \%$. So, most respondents were at the mean level on conflict understanding, and the percentage of persons, who didn't understand typical signs of conflict almost twice exceeded the one of them, who understood it.

The first scale of the diagnostic method provided the assessment of conflict as physical force application and demonstrated that the essential number of studied persons understood "conflict" just this way (26.67 \% - high level and $32.70 \%$ - middle). In such cases conflict is manifested, according to the opinion of the interrogated persons, as a scuffle, fight, battle and so on. But most respondents didn't find physical aggression at assessing a conflict (40.63\%) that testified to indirect coordination of these notions.

The next scale is the assessment of conflict as verbal aggression. Most respondents perceived conflict as misunderstanding in communication (52.70\%). They agreed that a conflict has signs of quarrel, scandal, defamation, controversy and so on. The high $(21.59 \%)$ and low (25.71 \%) manifestation levels of the studied scale was fixed within $20 \%$. Such respondents completely agreed or absolutely disagreed with a connection between conflict and communication.

The third scale of the diagnostic method provided the assessment of conflict as a psychological incompatibility of situation participants. The overwhelming majority of respondents assessed conflict as a psychological misunderstanding, incompatibility of interaction participants in the process of conflict, discordance in ideas about ways of conflict solution $(61.59 \%$ - middle level of manifestation, $18.09 \%$ - high). The low level of manifestation was revealed in $20.32 \%$ of the studied persons, who didn't find a conflict base in psychological incompatibility.

The obtained results proved that only one fifth of the respondents $(20.64 \%)$ distinctly understood essential signs of the notion "conflict", perception mechanisms of conflict situations (high 
level); a half of the studied persons (50.16\%) was partially able to characterize the studied phenomenon (middle level), and one third $(29.20 \%)$ - didn't understand the content field of the notion "conflict" absolutely, had great difficulties at comparing this notion with other ones (low level). The obtained empirical data testified that students didn't acquire proper knowledge on this problem during the life process, didn't have ideas about solving strategies of conflict situations. It proved the necessity to conduct the purposeful work as to explication of the essence of conflict and other notions, connected with it ("bullying", "mobbing", "violence" and so on).

For raising the level of students' knowledge and developing abilities and skills for prophylaxis and prevention of bullying among youth, different learning forms and methods were used at higher educational institutions. Thus, students were offered to work with cases: solving a relation conflict "Bullying", overcoming of an interest conflict "Student life", reconcilement of a relation conflict "Conflict situations from school life" and so on. Cases included situations from real life of certain classes and educational institutions, taught students to react fast and effectively to conflict situations. Cases were presented both in the native language and in a foreign one that provided discussion of a certain conflict situation and correspondent training of communication skills in a foreign language, development of the ability to practical realization of students' communicative abilities and skills. Special attention in the work with cases was paid to problem questions, for example:

- Find in fiction works, concerning ways of prevention and prophylaxis of conflicts. Name this ways.

- Prepare and play diverse situations of negotiations with different psychological types of business partners at the lesson.

- Choose such conflict situations of negotiations from literature works and analyze a course and psychological mechanisms of their deployment.

There was also initiated a webinar on the topic "Bullying at school: what to do?" (60 min), directed on elucidation of the following questions:

1) Bullying in the modern society.

2) Signs and manifestations of bullying.

3) Types of bullying.

4) What to do, if your child became a victim of bullying?

5) What to do, if you became a witness of bullying?

6) What to do, if your child is an aggressor?

7) The role of pedagogical workers in prevention and counteraction of bullying.

8) Responsibility for bullying.

Students formulated recommendations for children, teachers, parents, side people as to behavior in bullying situations according to these main directions. The webinar site was active and gave a possibility to put questions and get answers online to all participants.

The webinar results were presented by students at pedagogical practice at school. Future teachers of foreign languages had conversations with pupils, training exercises, made messages as to this problem as mini-lectures at parents' meetings. At the same time, students studied cases of bullying manifestations at school; worked individually with schoolchildren, who were victims, aggressors, witnesses and defenders in bullying; discussed an activity of famous people, devoted to the problem of bullying.

Such work was useful not only for pupils at school, but also students, who overestimated their own approaches to school terror, invented effective strategies for fighting against this phenomenon.

We find prospects of further research in elaboration of programs of school bullying prophylaxis, definition of effective pedagogical conditions of conflictological competence formation of future teachers of foreign languages, consideration of ways of mobbing prevention and so on.

\section{Conclusions}

The problem of bullying needs elaboration of the system of prophylactic arrangements on prevention and overcoming of this negative social and psychological-pedagogical phenomenon in 
the process of training future teachers of foreign languages and is a component of their conflictological competence formation. The obtained experimental results testify that future teachers of foreign languages consider the following assessing categories as a semantic kernel of the term "conflict": scuffle, quarrel, controversy, abuse, misunderstanding, defamation. So, the studied notion is associated in students with physical violence and verbal offences.

The conducted interrogation demonstrated that only one sixth of respondents understood essential signs of conflict, the most half accented attention on its unessential manifestations. The obtained empirical data shows that the students did not get adequate knowledge in the course of their life on the identified problems, had no idea about conflict situations solving strategies. For raising the level of students' knowledge and developing abilities and skills for prophylaxis and prevention of bullying, the following effective working forms were offered in the process of experimental work: acquaintance with the bullying problem by solving cases, conducting webinars, individual conversations with pupils at pedagogical practice, making messages as to this problem as mini-lectures at parents' meetings and so on.

\section{References}

[1] School Crime Supplement (SCS) to the National Crime Victimization Survey (2017). Department of Justice, Bureau of Justice Statistics, 61.

[2] Yelchaninova, T., Pidchasov, Ye., Ziza, Ye., Karlashova, L., Filippska, I. (2018). Psychological training of teachers for identification and pre-vention of manifestations of bullying among the studying youth. Visnik HNPU imeni G.S. Skovorodi Psihologija, 57, 103-118. doi: http://doi.org/10.5281/zenodo.1184274

[3] Kayris, E., Samoylenko, A. (2016). Psychological features of interpersonal relationships university students with experience of school bullying. The pedagogical process: Theory and Practice, 1, 26-29. Available at: http://nbuv.gov.ua/UJRN/ pptp_2016_1_7

[4] Bradshaw, C., Waasdorp, T., Pas, E., Larson, K., Johnson, S.; Gordon, J. (2018). Coaching Teachers in Bullying Detection and Intervention. Bullying Prevention and Intervention at School. Cham: Springer, 53-72. doi: http://doi.org/10.1007/9783-319-95414-1_4

[5] Murphy, H. R., Tubritt, J., O’Higgins Norman, J. (2018). The Role of Empathy in Preparing Teachers to Tackle Bullying. Journal of New Approaches in Educational Research, 7 (1), 17-23. doi: http://doi.org/10.7821/naer.2018.1.261

[6] Onufriieva, L., Honcharuk, N. (2019). Psychological principles of bullying at juvenile age. Psychological journal, 2 (22), $25-39$. doi: http://doi.org/10.31108/1.2019.2.22.2

[7] Kormylo, O. (2015). The Phenomenon of Bullying in the Educational Space. Problems of the Humanitarian Sciences. Psychology Series, 35, 174-187.

[8] Koval, H. V., Alyeksyeyenko, H. O. (2016). Contemporary approaches to definition and classification of bullying in school teenage collectives. Naukovi pratsi Chornomorskoho derzhavnoho universytetu im. Petra Mohyly kompleksu «Kyievo-Mohylianska akademiia». Seriia: Pedahohika, 269 (257), 7-11. Available at: http://nbuv.gov.ua/UJRN/Npchduped_2016_269_257_3/

[9] Olweus, D. (1978). Aggression in the schools: Bullies and whipping boys. Oxford: Halsted Press, 218. doi: http://doi.org/ 10.1002/1098-2337(1979)5:3<309::AID-AB2480050307>3.0.CO;2-S

[10] Borshchevska A. V. (2014). Bulinh u shkolakh yak chynnyk psykhichnoho nezdorovia. Naukovyi visnyk Mizhnarodnoho humanitarnoho universytetu. Seriia: Medytsyna, 6, 48-52. Available at: http://nbuv.gov.ua/UJRN/Nvmgu_medf_2014_6_15

[11] Butuzova, L. P. (2018). Psykholohichnyi retrospektyvnyi analiz uiavlen maibutnikh pedahohiv pro shkilnyi bulinh. Visnyk Kyivskoho instytutu biznesu ta tekhnolohii, 3 (37), 3-8.

[12] Mysenko, O. V. (2005). Modyfykatsyia metodyky yssledovanyia osobennostei mezhlychnostnoho vospryiatyia v konflyktnoi sytuatsyy. Praktychna psykholohiia ta sotsialna robota, 5, 23-27. 